\section{Cortisone and Corticotrophin}

The November issue of The Practitioner is devoted to a consideration by a number of authorities of the value and dangers of the hormones cortisone and corticotrophin (ACTH). Until recently, supplies of both these drugs in Great Britain were not adequate ; but now there are good reasons for believing that supplies of them will soon be enough to satisfy all needs. They are, in most instances, used empirically, because we do not yet know enough about how they act; but their value in carefully selected cases is very apparent from Dr. C. L. Cope's article on their pharmacology and from the other articles by experts who discuss their uses for treating chronic rheumatic diseases, gout, rheumatic fever, certain diseases of the skin, the eye, the endocrine glands and blood, and for asthma, or as an aid to surgery. To summarize these articles in a brief review is impossible, and would be dangerous; indeed, it would not be wise to epitomize, or take out of the context, the scope and content of Prof. E..J. Wayne's contribution on the dangers and complications of the use of these drugs. Nevertheless, an indication of the general position can be gathered from the opinion expressed on the first page of the issue that "the practitioner will not go tar wrong if he continuously bears in mind the advice given by Prof. Wayne that, in cases of doubt, it is better to be cautious in deciding to give these drugs". Prof. Wayne, however, also says that fifteen years age the text-books "devoted pages to the side effects of sulphonamides, but they are still used in considerable quantities and with good effect".

The South African Museum, Cape Town (18551955)

The centenary of any organization is an appropriate time to publish details of its origin and progress. The South African Museum at Cape Town has thus just published an admirable booklet to celebrate that event (pp. $23+4$ plates; 1955). As with so many museums of the early and middle nineteenth century, it was founded on the pattern of the British Museum in London. It is indeed fortunate in that as early as 1855 the trustees realized that the Museum should be a place of education combined with recreation and also a centre of research on the natural products of South Africa. It was not until 1897 that the Museum acquired a second and more adequate building, and now it is rightly suggested that the centenary should be marked by additional galleries. This would enable the greatly increased collections to be more properly preserved and the display to be modernized. The booklet gives a brief description of the principal acquisitions since 1855, and an important section deals with the field-work that the Museum has been able to organize.

\section{British Nuclear Energy Conference : Meeting in London}

The British Nuclear Energy Conference, which has been formed by the Institutions of Civil, Mechanical, Electrical, and Chemical Engineers and the Institute of Physics (see Nature, June 11, p. 1023), will hold its first meeting in the form of a lecture symposium, to be held at the Institution of Civil Engineers (Great George Street, London, S.W.1) on November 30 (2.15-8.15 p.m.) under the chairmanship of Sir Christopher Hinton. Lectures will be delivered as follows : the United Kingdom Atomic Energy Project (Sir John Cockcroft) ; the place of nuclear energy in United Kingdom power development (V. A. Pask and J. C. Duckworth); the use of research reactors in nuclear power development (H. J. Grout); and health and safety in a nuclear power industry (A. S. Maclean and Dr. W. H. Marley). The papers will be published in the new B.N.E.C. Journal of the Conference (see Trans. Inst. Chem. Eng., 33, No. 2; Oct. 1955). Attendance at the symposium will be confined to members of the five member bodies concerned, and those who wish to attend should write as soon as possible to the secretary of their particular professional body.

\section{Atomic Energy Exhibit at British Industries Fair}

THE "Atoms for Britain" exhibition, shown at Geneva during the Conference on the Peaceful Uses of Atomic Energy, will be seen for the first time in Britain at next year's British Industries Fair. It is to be presented by the U.K. Atomic Energy Authority and will be a major feature in the electrical and electronics sections of the Fair at Olympia, London, during April 23-May 4. The exhibition, which covers 7,000 sq. ft., will show Britain's progress in harnessing nuclear power and in using atomic energy in industry, agriculture and medicine. The research carried out at Harwell will be illustrated by largescale models, photographs and diagrams. One of the models will be of DIDO, the 'heavy-water' research reactor which will be completed by next summer. A model of Britain's first atomic power station now being built at Calder Hall, Cumberland, will also be on show. This station, which is scheduled to start feeding electricity into the national grid at the end of next year, is the first of twelve to be built in Britain during the next ten years. Another model on display will be of a more advanced and experimental type of power unit now under construction at Dounreay, Caithness. The uses of radioactive isotopes will also be shown.

\section{First International Congress on Documentation of Applied Chemistry}

THE first International Congress on Documentation of Applied Chemistry will be held in London during Nóvember 22-25, at the Institut Français, Queensberry Place, South Kensington. The Congress is under the patronage of the International Union of Pure and Applied Chemistry, and the president of honour is Lord Cherwell, Dr. Lee's professor of experimental philosophy in the University of Oxford, who will open the first session. The Congress is confined to one particular field, namely, applied chemistry, and although not the first of its kind it is the first conference at an international level at which a serious attempt has been made to bring together librarians and information officers, on one hand, and the applied chemists, who use the information they supply, on the other. On November 23 two sessions will be held on the international and national scenes, respectively, with Dr. L. H. Lampitt and Sir Alfred Egerton as chairmen. On November 24 two sessions will be devoted to particular problems, with Prof. F. Velander (Sweden) and Prof. A. Nasini (Italy) as chairmen. On the last morning, the Congress, with Prof. W. Albert Noyes (United States) as chairman, will look to the future. At the final session in the afternoon there will be an open discussion on the problems raised during the various sessions and a paper giving a summary of the proceedings; a valedictory address will be given by Sir William Ogg, director of the 